\title{
フィルダムに作用する地震力およびその簡易 推定法
}

\author{
松本徳久*・安田成夫** • 山邊建二***
}

フィルムダムに作用する地震力を, 1 次元および 2 次元の動的応答解析手法を用い, 深さの異なるすべり土塊に作用する平均加速度を求めることにより評価した．入力地震 動の周波数特性とすべり土塊に作用する地震力の関係を求め, この結果を用いることに より地震動の加速度応答スペクトルから任意の深さのすべり土塊に作用する地震力を簡 易に推定する手法を開発した。.また,この結果と堤体材料の室内繰り返し試験を組み合 わせて, 永久ひずみを推定する方法を示した.

Keywords : embankment dams, seismic design, earthquake motions, response spectrum

\section{1. まえがき}

本論文は，基盤における地震動の周波数特性とフィル ダム堤体に作用する地震力の関係を論じたものである. すなわち種々の周波数特性の入力地震動に対して堤体の 応答を求め, 地震力の周波数依存性を明らかにし, さら に, 地盤の地震動加速度応答スペクトルから簡易に地震 力を求める手法を開発した.

Newmark ${ }^{1)}$ や Seed ${ }^{2)}$ 以来, 繰返し荷重を受けて強度 低下することのない材料で築造されているフィルダムで は, 地震時の堤体の安全性を地震によって生じる堤体の 永久変形から評価する方法が発展してきた. この永久変 形量の計算では, Fig.1に示すように，堤体内に仮定し たすべり土塊に作用する地震時慣性力をその土塊の質量 で除すことによって得られる平均化された加速度 (Average acceleration：以下 $\bar{a}$ ) とその地震動継続時間 中の最大值 (Maximum average acceleration : 以下 $\left.\bar{a}_{\max }\right)$ が主要なパラメーターとなる.すなわち，すべり 土塊の安全率を 1.0 とする加速度を限界加速度 (Yield acceleration : 以下 $a_{y}$ ) とすると, フィルダムの地震に よる変形量は $\bar{a}$ が $a_{y}$ を越えた時刻よりすべりが始まる との考えから求められるが, 近似的には単に $a_{y}$ 亡 $\bar{a}_{\max }$ の比から推定できる. 例えば, Watanabe et al. ${ }^{3)}$ は周 期 0.125 秒から 0.625 秒までの 5 種の正弦波入力に対し て, Newmarkの方法によるすべり計算を行い, 天端の 永久変形量は, すべり土塊の位置によらず $\bar{a}_{\max }$ と $\bar{a}$ が $a_{y}$ を越える地震動継続時間の 2 乗に比例するとしてい る. また Makdisi et al. ${ }^{4)}$ は実地震波に対する New-

*正会員 . 工博 (財)ダム技術センター 首席研究員 (前建設省土木研究所 フィルダム研究室 室長) （テ106 東京都港区麻布台 2-4-5）

**正会員 建設省土木研究所 フィルダム研究室 主任研究員

***正会員 (株)建設技術研究所 大阪支社水工本部 技術

第 1 部 (元土木研究所部外研究員)

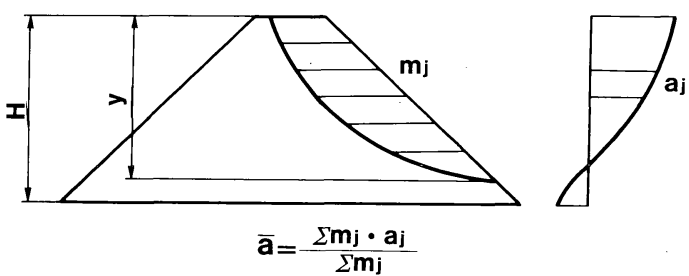

Fig.1 Average acceleration as a function of $\mathrm{y} / \mathrm{H}$

mark の方法によるすべり計算から,地震のマグニチュー ド別の永久変形量と $a_{y} / \bar{a}_{\max }$ の関係を示している. さら に， $\bar{a}_{\max }$ は，実務で使用されている震度法による安定 計算において, 震度の概念亡密接な関係にあり, フィル ダム堤体に作用する地震力を表現している. 土の強度特 性を考えると 1 回の短時間の荷重では大きなひずみは進 行せず，ある一定回数以上の繰返し荷重を受けたときに ひずみが進行する.そこで，ある大きさ以上の $\bar{a}$ あ゙ー 定回数以上繰返すときその $\bar{a}$ を等価加速度 (Equivalent acceleration : 以下 $\bar{a}_{e q}$ ) とし，これをもって震度法 の震度とする Seed et al. ${ }^{5)}$ の考え方もある. 当初 Seed et al. ${ }^{5)}$ や Ambraseys et al. ${ }^{6)}$ によってダム堤体を均質 な三角形でモデル化し，すべり面を直線で近似した ウェッジ形のすべり土塊の $\bar{a}_{\max }$ は，すべり土塊の標高 および堤体の固有周期によって異なることが明らかにさ れた.これらの数值解析においてすべり土塊の $\overline{a_{\max }}$ の 算定は Mononobe et al. ${ }^{7)}$ によるせん断梁理論の 1 次元 動的解析手法が用いられた。.のちに Chopra ${ }^{8)}$ にって, 1 次元のせん断梁理論で求められた $\bar{a}_{\text {max }}$ が有限要素法 による 2 次元動的解析のそれと比べて平均的に 10 $20 \%$ 程度，大きめとなることが示された。

$\bar{a}_{\max }$ は, Fig.1 に示すように堤高を $H$, 天端標高とす ベり円弧の最低標高の差を $y$ としたとき, $y / H$ の関数 となる， $\bar{a}_{\max }$ を天端の最大応答加速度 $\ddot{u}_{\max }$ で除し無次 元化し, これと $y / H$ の関係でプロットすると無次元化 


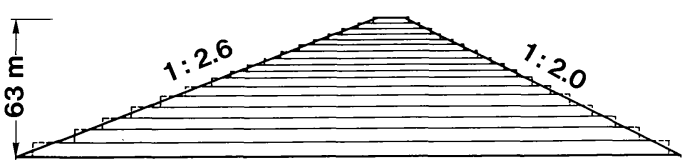

(a) One-dimensional

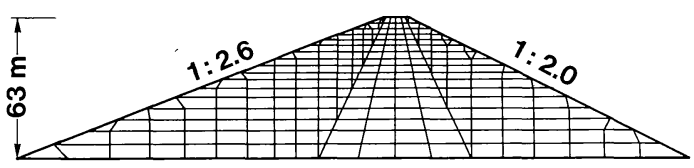

(b) Two-dimensional

Fig.2 Finite element idealization used in the analysis

した $\bar{a}_{\max }$ の曲線（以下単に加速度曲線）が得られる。 Makdisi et al. ${ }^{4)}$ によれば，加速度曲線は解析方法の 1 次元亡 2 次元とでは大きな差異はなく, 堤体の固有周期 によってある程度の変動があるものの, 平均值を採用し たとき, 変動の上下限は上位標高で $\pm 10 \%$ 土 $20 \%$, 下位標高で $\pm 20 \%$ $\pm 30 \%$ の範囲にあり，平均値を実 務上の設計曲線として使用してよいとされる. ただし安， 全側の設計を行うときには平均值よりも10３0\% 大き めの值を使うことが推奨されている. 加速度曲線から地 震力を求めるときには, $\ddot{u}_{\max }$ を定める必要があるが, Makdisi et al. ${ }^{9)}$ は設計地震動の加速度応答スペクトル と 1 次元せん断梁理論によるモード重畳法から 2 乗平均 によって簡易に求める手法を提案している. Luan et al. ${ }^{10)}$ は堤体法勾配，減衰定数，材料のせん断強度から 定まるすべり面形状が加速度曲線に与える影響を研究 し，加速度曲線は Makdisi et al. の結果が中位標高以 下では過小の側にあること, 堤体の法勾配および材料強 度にはほぼ無関係であるとの結論を得た。

$\bar{a}_{\max }$ は以上のように, 解析手法, 堤体の形状, すべ り土塊の標高, 堤高, 物性值との関連で研究されている が, 入力地震動の周波数特性との関係についての研究が ほとんどない. そこで本論文では， $\bar{a}_{\max }$ と入力地震動 の周波数特性の関係を論じ，功加速度応答スペクトル から簡易に求める手法をとりま亡め, さらに $\bar{a}_{\max }$ を使っ て堤体に生ずる残留ひずみを求める手法を示したもので ある。

\section{2. 解析モデルと解析手法}

\section{（1）モデルダム}

解析に用いたモデルダムは上下流方向断面を対象之 し, 上流面勾配 $1: 2.6$, 下流面勾配 $1: 2.0$, 高さ $63 \mathrm{~m}$ 亡設定している. 1 次元動的解析では, Fig.2(a), 2 次 元動的解析の場合はFig.2(b)を用いる.

\section{（2）モデルダムの物性值}

ロックフィルダムの築堤材料は大半がロック材料であ

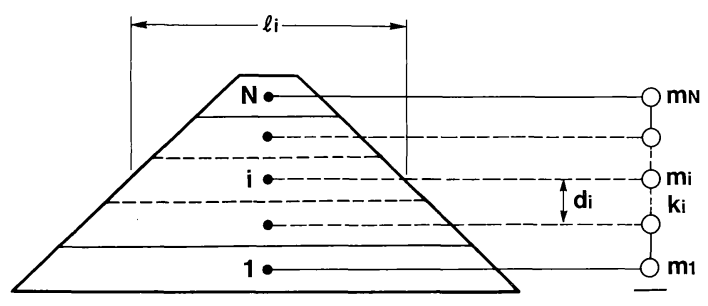

Fig.3 Shear beam model with lumped mass (Modal Analysis)

り，フィルタ材料およびコア材料の物性值を解析に考慮 してもその与える影響は小さいと考え，モデルダムの物 性值は堤体全体についてロック材料の物性值を与えた. せん断弾性係数 $G$ はせん断ひずみ $\gamma$ に依存するが, 三 軸試験結果 ${ }^{11)}$ に基づき, 微小ひずみ $\left(\gamma<10^{-5}\right)$ 時の $\mathrm{G}$ を $G_{0}$ として $\gamma=5 \times 10^{-4}$ のひずみのときの $G$ は $G_{0}$ の $60 \%$ に低下するよう定めた. また， $G_{0}$ は拘束圧に応じ て, $\sigma_{m}$ を平均主応力としたとき, 式( 1 )で与えた.

$$
G_{0}=1100 \times\left(\sigma_{m}\right)^{0.85}
$$

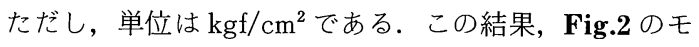
デルの一次固有周波数 $f_{0}$ は, $1.7 \mathrm{~Hz}$ となった. 減衰定 数は, 材料自体の内部減衰と, 基礎岩盤・貯水池などの 境界条件に関わる逸散減衰から成っている. 材料の内部 減衰は，ひずみが大きいときには三軸試験結果から 10\% 程度ある.また, 貯水位がある場合逸散減衰が増加する ことは実験上も認められており ${ }^{12)}$, Ohmachi et al. ${ }^{13)} の$ 実測からは満水時には約 $10 \%$ 程度になることが示唆さ れている. したがって, 満水時における大地震時の減衰 定数は全体で約 $20 \%$ 程度ということになる. また，既 往の研究4),6),8),9),10) においても $20 \%$ の減衰定数が解析に 用いられており, 既往の研究との結果の比較の便も考慮 し，ここでは $20 \%$ と設定した.

\section{（3）解析手法}

動的解析手法としては, 1 次元動的解析のモード重畳 法, SHAKEM ${ }^{14)}$ と 2 次元動的解析のQUAD-4 ${ }^{15)}$, $\mathrm{FLUSH}^{16)}$ の 4 手法を用い, 各々の手法ですべり土塊の $\bar{a}$ を算出した. なお, すべり面の形状は, ダムの構造と 材料強度特性に関係し, 円弧, ウェッジ, 複合など種々

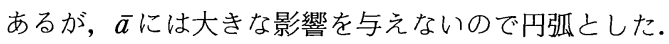

モード重畳法は, 多質点系構造物の振動を規準振動形 の直交性を利用することにより 1 自由度系の振動の重秝 合わせで表現し，これにより地震時における構造物の応 答解析を行う手法である17). モード重盢法をフィルダム に適用するにあたっては, Fig.3 に示すようにダムを質 点とバネでモデル化した. 質点は各層の全重量 $m_{i}$ を各 層の重心位置に設定し，バネは質点間に配置する．添字 の $i$ は質点番号を表している. 奥行方向の単位幅当りの バネ定数 $k_{i}$ は式( 2 ) で与えられる. 
Table 1 Characteristics of earthquake motions observed at dam foundation

\begin{tabular}{|c|l|l|c|c|c|c|}
\hline Case & DAM site & \multicolumn{1}{|c|}{ Earthquake } & $M$ & $L(K M)$ & $f(H z)$ & $f / f o$ \\
\hline 1 & Gosho & Mid Japan Sea & 7.7 & 198.0 & 0.59 & 0.35 \\
\hline 2 & Minase & Miyagi offshore & 7.4 & 167.0 & 0.78 & 0.46 \\
\hline 3 & Yokoyama & Central Gifu & 6.6 & 60.0 & 1.07 & 0.63 \\
\hline 4 & Tokachi & Northern Hidaka Mts. & 7.0 & 62.0 & 1.61 & 0.95 \\
\hline 5 & Tase & Mid Japan Sea & 7.7 & 264.0 & 2.39 & 1.41 \\
\hline 6 & Gosho & Central Iwate & 6.6 & 69.0 & 3.20 & 1.88 \\
\hline 7 & Miho & Izu peninsula offshore & 6.7 & 56.0 & 4.15 & 2.44 \\
\hline 8 & Miho & Western Kanagawa & 5.8 & 12.0 & 6.59 & 3.88 \\
\hline
\end{tabular}

(Note) $\mathrm{M}$ : Magnitude L: Epicentral distance

fo: Natural frequency of model dam $f$ :Predominant frequency

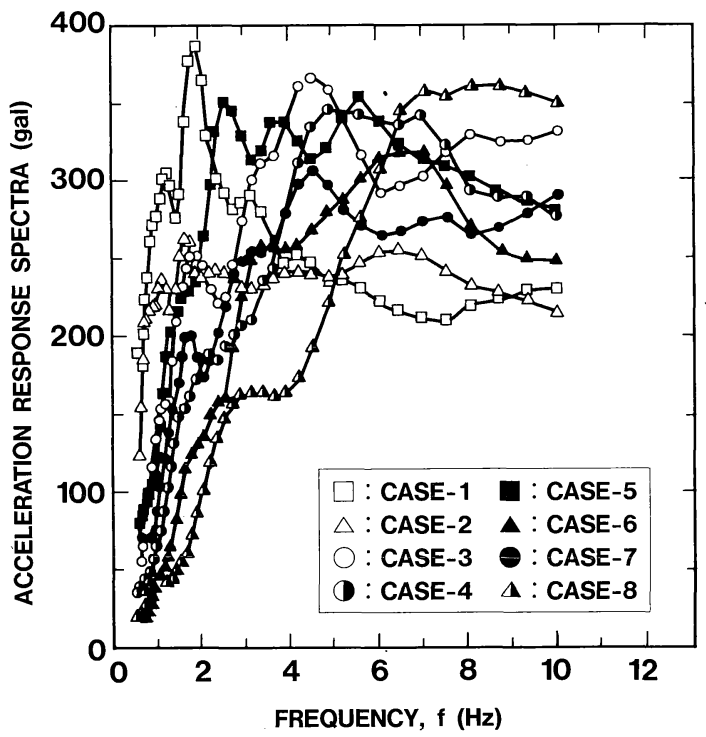

Fig.4 Acceleration response spectra for input ground motions $(h=20 \%)$

$k_{i}=\frac{l_{i} G_{i}}{d_{i}}$

ここに， $l_{i}$ は質点（重心）位置におけるダムの幅で, $d_{i}$ は質点間の距離, $G_{i}$ はせん断弾性係数を表している.

$i$ 層より上部のすべり土塊の $\bar{a}$ は次式で算定される.

$\bar{a}=\frac{F_{i}}{\sum_{s=i}^{N} m_{s}}$

ただし $F_{i}$ は $i$ 層と $(i-1)$ 層間で㗢くせん断力であり， $F_{i}=k_{i} \times\left(y_{i}-y_{i-1}\right)$ で表される.ここに, $y_{i}$ は $i$ 層の質 点の変位である.

SHAKEM はSHAKE ${ }^{18)}$ を有限地盤に適用できるよ うに改良したものである。この手法におけるすべり土塊 の $\bar{a}$ は, 円弧内の各層の面積で重みをつけた平均値で 算出した.

QUAD-4, FLUSH におけるすべり土塊の $\bar{a}$ は, 円 弧内の節点を共有する要素面積の重み付きで算出した.

\section{（4）入力地震動}

入力地震動は本来設計対象亡する地震の特性に応じて 決められるべきものである，岩盤における実測加速度記 録によると, 同一のダムサイトで, 同じ程度のマグニ チュードの地震であっても地震そのものが異なると地震 動の周波数特性が著しく異なる場合があり，安全側の設 計の立場からは, 入力地震動には種々の周波数特性のも のを想定しておくべきと考える．したがって，本論文で は入力周波数特性が堤体に作用する地震力に及ぼす影響 に着目して, 入力地震動最大加速度 $\ddot{u}_{\mathrm{g}}$ は一定の $0.2 \mathrm{~g}(\mathrm{~g}$ ：重力加速度）とし，周波数特性の異なる種々の実地震 動を用いた応答解析を実施した．入力波形は，ダムサイ 卜岩盤で観測された基盤の地震動記録から，地震動の フーリエスペクトルの卓越周波数に着目して周波数特性 の異なる 8 地震動を選定し $\ddot{u}_{g}=0.2 \mathrm{~g}$ 亡なるよう振幅を 調整して使った。地震動の諸元をTable 1 に示す.

Fig.4 は Table 1 の 8 個の地震動の減衰定数が $20 \%$ の 時の加速度応答スペクトルを示したものである.

\section{3. 予備的検討}

\section{（1）鉛直動の影響}

まず予備的検討として，すべり土塊の $\bar{a}$ の算定にあ たり，応答加速度における鉛直成分および入力地震動に おける鉛直地震動の影響について検討した. 式(4) か ら求まるすべり土塊の加速度モーメント $M_{a}$ から鉛直応 答加速度と鉛直地震動の影響を評価することとした。

$$
M_{a}=\sum_{i=1}^{N}\left\{m_{i} \times\left(a_{H i} \times r_{V i}+a_{V i} \times r_{H i}\right)\right\} / \sum_{i=1}^{N} m_{i}
$$

ここで， $a_{H i}, a_{V i}$ はそれぞれ水平, 鉛直応答加速度であ り， $r_{H i}, r_{V i}$ は円弧の中心から要素質量 $m_{i}$ の重心まで の水平, 鉛直距離である. また, 鉛直地震動の影響を併 せて評価するにあたって, 以下の 3 ケースを設定した.

(1)地震動として水平地震動のみを入力し, 動的解析で 得られる水平応答加速度時刻歴を用いて $M_{a}$ を算出す る (Case@).

(2)地震動として水平および鉛直地震動を入力し, 動的 解析で得られる水平応答加速度時刻歴を用いて $M_{a}$ を 算出する (Case(b)).

(3)地震動として水平および鉛直地震動を入力し，動的 解析で得られる水平および鉛直応答加速度時刻歴を用 いて $M_{a}$ を算出する (Case`).

計算は二次元解析の QUAD-4 を用い, Fig.2(b) の モデルダムに対して実地震波を入力し，すべり土塊の $M_{a}$ の地震動継続時間中の最大値を求めた。なお，地震 動は Table 1 に示した実地震動の Case 5 を用いるが, ダムサイト岩盤で記録された地震動のうち，水平最大加 速度と鉛直最大加速度の比が $1 / 4 \sim 1 / 2$ の間にあること から ${ }^{19}$ 鉛直地震動の最大加速度は水平の $1 / 2$ とした. 


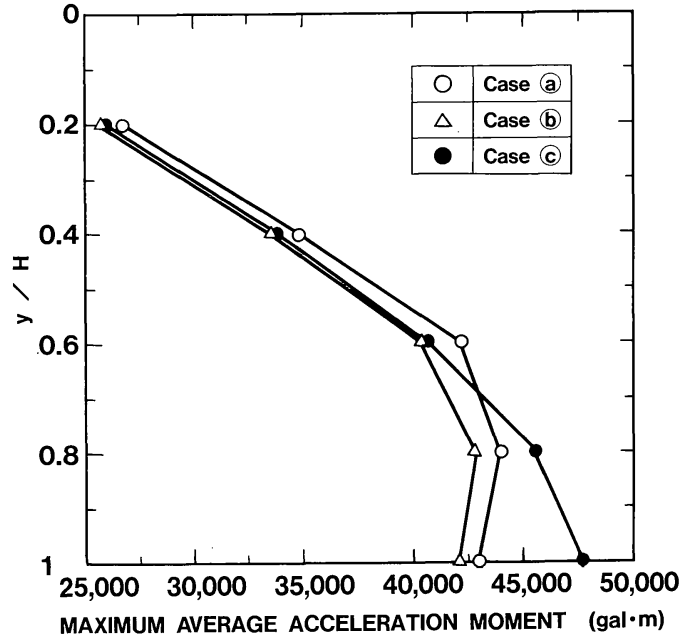

Fig.5 Maximum average acceleration moments

Fig.5 は計算結果であるが, 鉛直地震動の影響につい ては, Case@ と Case(b)はぼ同様な曲線形状を示し， (a)が全体にわたって (b) よりも $4.0 \%$ 程度大きめになっ ている. Case(a) とCase(c)を比較すると $y / H<0.6$ で 最大 $4.0 \%$ 程度 (c)が小さい. その関係は $y / H=0.7$ を 境にして逆転し,$y / H=1.0$ で最大約 $10 \%$ Case(c) の方 が大きくなる.このことから，入力地震動に鉛直成分お よび鉛直応答加速度を考慮した場合の $M_{a}$ への影響は水 平成分のみの場合に比べて高々 $10 \%$ と判断される.な お田村・岡本 ${ }^{20)}$ はフィルダムの安定性に及ぼす鉛直動 の影響について湿潤砂材料を使い正弦波加振に実験およ び解析結果に基づく評価を行い，水平動の $1 / 2$ の鉛直動 が作用する場合の効果は水平動が 10 ～20\% 程度大きく なったのと同じ程度の効果としている.

以上のことから鉛直動及び鉛直応答加速度の影響は少 ないと判断し, 計算を簡便にすることからも, 入力とし ては水平地震動のみ, 応答加速度も水平方向のみの Case(a)とすることとした.

\section{（2）平均加速度 $\bar{a}$ の算定方法}

すべり土塊の $\bar{a}$ は，一般に土塊に作用する水平力か ら求められるが, 土塊のモーメントから計算することも 考えられる. そこで以下で両者を比較する.

(1)土塊の円弧中心に関するモーメントが等価となる $\bar{a}$ を求める. すなわち, 水平応答加速度時刻歴 $a_{H i}$ と要 素質量 $m_{i}$, 円弧の中心から各要素重心までの鉛直距 離 $r_{v i}$ を用いて, $\bar{a}$ を次式で算定する (Cased).

$\bar{a}=\sum_{i=1}^{N}\left\{m_{i} \times a_{H i} \times r_{v i}\right\} / \sum_{i=1}^{N}\left(m_{i} \times r_{v i}\right)$

(2)土塊の水平力が等価となる $\bar{a}$ を求める. すなわち, 各要素の $a_{H i}$ と $m_{i}$ を用いて, $\bar{a}$ を式(6)で算定する (Case(e).

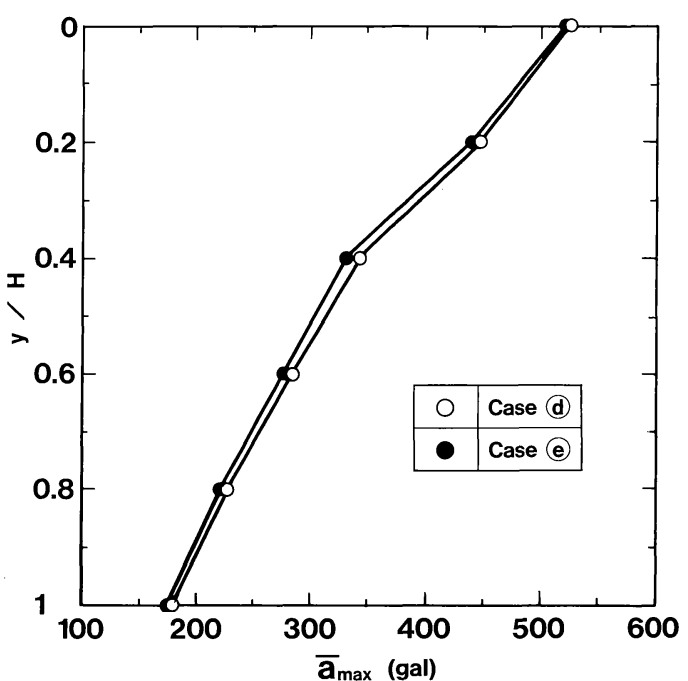

Fig.6 Maximum average accelerations computed from moment and horizontal force

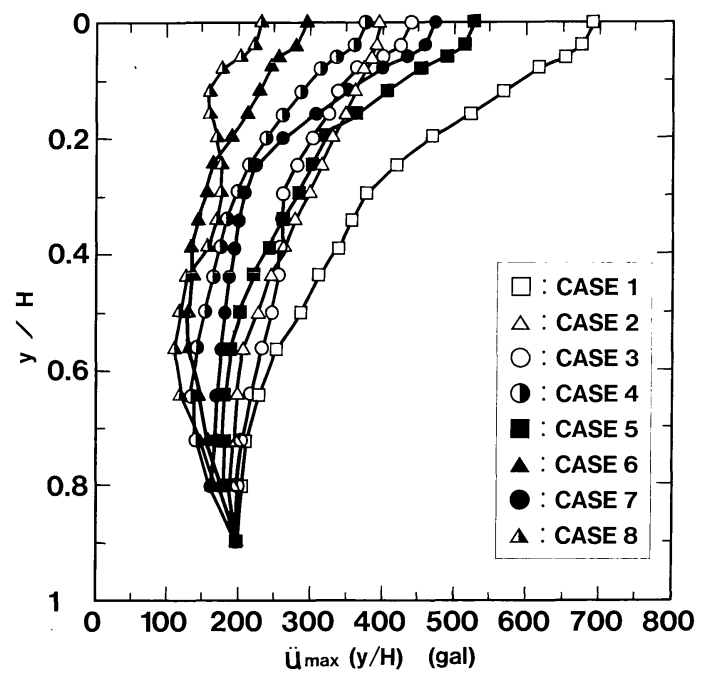

Fig.7 Maximum accelerations at various elevations from QUAD-4

$$
\bar{a}=\sum_{i=1}^{N}\left\{m_{i} \times a_{H i}\right\} / \sum_{i=1}^{N} m_{i} \cdots
$$

計算の結果，Fig.6に示すように式( 5 )，（6)で得ら れる $\bar{a}_{\max }$ がほぼ一致することから，以下では式(6) により $\bar{a}_{\max }$ を算定している。なお， $y / H=0$ における $\bar{a}_{\max }$ は天端の最大応答加速度 $\ddot{u}_{\max }$ とした.

\section{4. 最大応答加速度 $\ddot{u}_{\max }(y / H)$ と 最大平均加速度 $\bar{a}_{\text {max }}$}

堤体標高 $y / H$ の位置 ( 2 次元モデルの場合は堤体中 央）における入力地震波に対する応答加速度の最大值を $\ddot{u}_{\max }(y / H)$ とする. Table 1 の 8 波に対してQUAD-4 


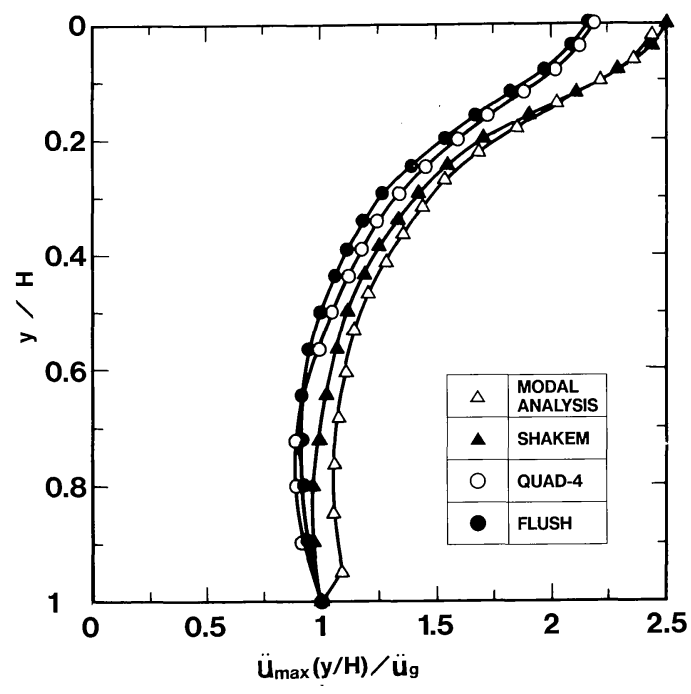

Fig. 8 Averages of maximum accelerations of 8 cases at various elevations from four different calculation methods

を使い $\ddot{u}_{\max }(y / H)$ を求めたのが Fig.7 である. 入力 8 波はすべて $\ddot{u}_{g}=0.2 \mathrm{~g}$ であるから, Fig.7の $\ddot{u}_{\max }(y / H)$ の差は主として周波数特性の影響である. Fig.7を QUAD-4 以外の 3 手法についても求め, 8 波の平均值 を $\ddot{u}_{g}$ で除して応答倍率としたものが Fig.8である. 8 波の平均応答倍率は $y / H>0.5$ ではおよそ $1.0, y / H=$ 0.5 より高い標高では標高とともに増加し, $y / H=0$ (天 端)で 2.2〜2.5 となっている.ここには示していないが， Table 1 の地震波の他に周波数が 1.0，1.5，2.0，3.0， $4.0 \mathrm{~Hz}$ の 5 波の正弦波についても計算を実施した（詳 細は文献 21). これらを総合すると各解析手法が $\ddot{u}_{\max }$ $(y / H)$ に対する影響は以下のようである. $2 \mathrm{~Hz}$ 以下の 低周波数の入力地震動に対しては，4手法ともほとんど 同一の $\ddot{u}_{\max }(y / H)$ を与える. 高周波になるほど 1 次元 のモード重畳法と SHAKEM は 2 次元のQUAD-4, FLUSH より大きな $\ddot{u}_{\max }(y / H)$ を与える. 同じ 2 次元 の QUAD-4 と FLUSH を比べると, 低周波ではほとん ビ同じ結果を与えるが，高周波では，FLUSH の方が QUAD-4 よりも各 $y / H$ においてやや大きな $\ddot{u}_{\max }(y / H)$ を与える.これはレイレイ減衰 (QUAD-4) と複素減 衰（FLUSH）の差である. Table 1 の 8 波の平均では， 1 次元解析は 2 次元解析に対して約 $10 \%$ 大きい. また, $\bar{a}_{\max }$ について 1 次元は 2 次元に比し Table 1 の 8 波平均 で 10〜 $15 \%$ 大きい. したがって， $\bar{a}_{\max }$ の算定にあたっ ては, 入力が著しく高周波でない限り，計算時間が短く 経済的な 1 次元の解析すなわちモ一ド重畳法あるいは SHAKEM を使ってもほぼ満足できる結果を得られるこ とがわかる.

Figs.7, 8 に示される計算値 $\ddot{u}_{\max }(y / H)$ を実物ダムの 地震時挙動と比較してみよう. Fig.9 (a) は建設省所管の

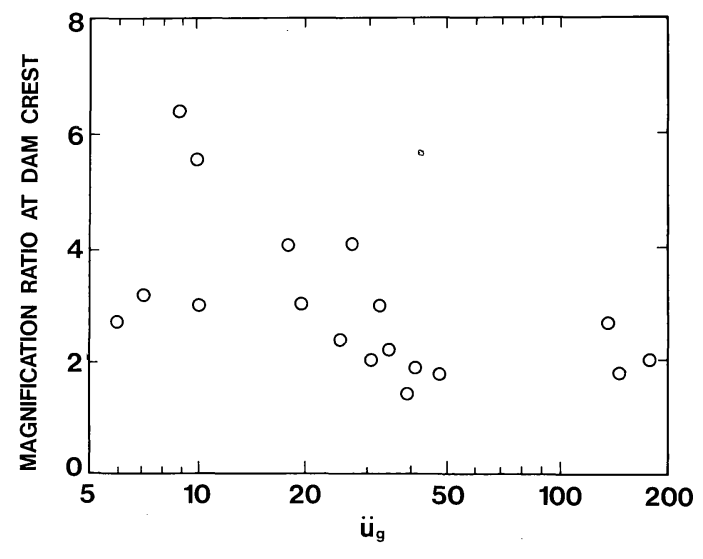

(a) Maximum acceleration magnification ratio at dam crest with maximum ground acceleration

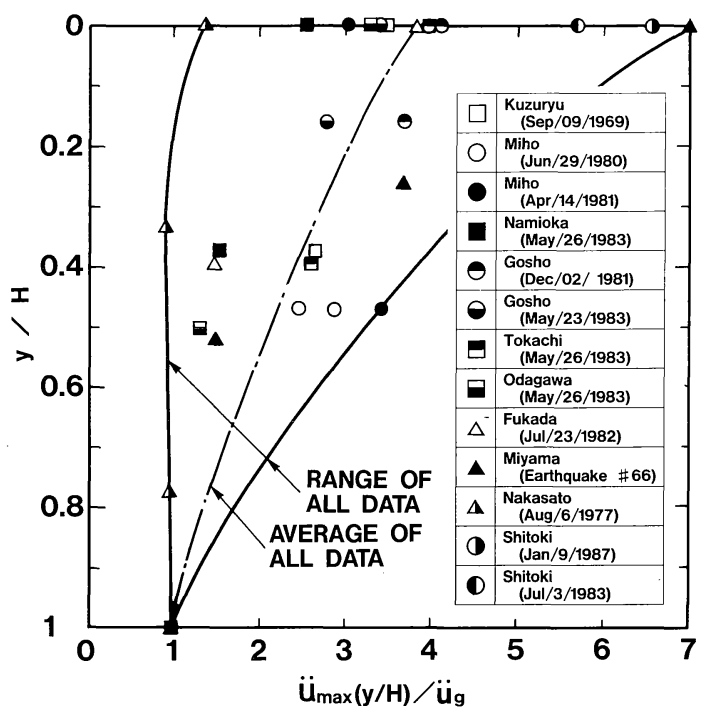

(b) Maximum acceleration distribution with elevations

Fig.9 Acceleration response measured at rockfill dams

フィルダムにおいて実測された天端での応答倍率と $\ddot{u}_{g}$ の関係である.この図によれば $\ddot{u}_{g}$ が $20 \mathrm{gal}$ 以下では応 答倍率は 3 ～倍程度あるが $\ddot{u}_{g}$ が増加すると低下し, 特に $100 \mathrm{gal}$ 以上では $2 \sim 2.5$ 倍となっている.このこ とはひとつにはひずみの増加とともに減衰暗加する非 線型性による. ふたつには $\ddot{u}_{g}$ の小さな地震は震央距離 の遠いものが多く地震動の周期が比較的長く堤体の共振 点付近にあるが， $\ddot{u}_{g}$ の $100 \mathrm{gal}$ を越えるものはダムサイ トに近いマグニチュードの小さな地震によるもので高周 波であることによる.つまり，Fig.9(a)の $\ddot{u}_{g}$ が $100 \mathrm{gal}$ を越えた地震動の周波数特性は, Table 1 の入力地震動 で言えば Case 6 - 8 に相当するわけで, Fig.7におい て Case 6 - 8 の $y / H=0$ におけ $\ddot{u}_{\max }(y / H)$ が $\ddot{u}_{g}$ の $1.5 \sim 2.5$ 倍にあることは実測に一致している.また 


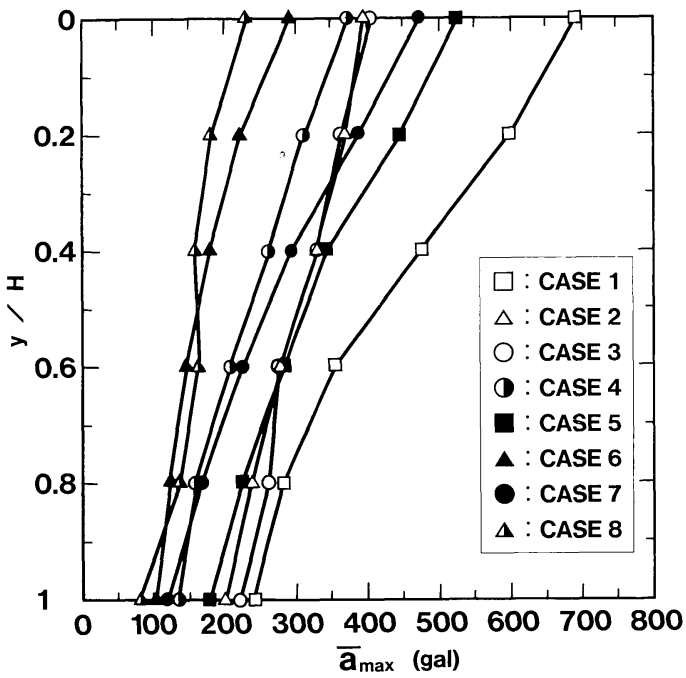

Fig.10 Maximum average accelerations from QUAD-4

Fig.9 (b) は手持ちの建設省のダムの実測データに, 文 献22) 26) に記されている結果を加えて整理したフィルダ ムの標高別の最大加速度分布である.この図には， $\ddot{u}_{g}$ が $5 \mathrm{gal}$ 程度のものも含まれており, 減衰が小さいため に応答倍率はFig.7に比し全体に大きめであるが,

Fig.7の分布はFig.9 (b)の下限值と平均值の範囲にあ る. 本論は, 解析と実測の比較を目的としたものでない ので比較の詳細検討にはこれ以上立ち入らないが, 応答 倍率はダム堤体の固有周波数と入力波形の周波数の関係 および減衰定数によって決まるから, 本論で用いた物性 值特に減衰定数は地震動の大きい入力の場合実測と予盾 していないと考えられる.

各地震動に対する円弧すべり土塊の $\bar{a}_{\max }$ と $y / H$ の関 係をFig.10に示す. $\vec{a}_{\max }$ はQUAD-4により求めた. $y / H$ が大きくなると, すなわち円弧が深くなると $\bar{a}_{\max }$ は小さくなり,ダム基礎に接するすべり土塊 $(y / H=1)$ の $\bar{a}_{\max }$ はC Case 1 を除いて基盤加速度の最大值 $\ddot{u}_{g}(=0.2$ g）にほぼ等しいかそれより小さい. また, 地震動の卓 越周波数が高いCase 6 ～ 8 は特にダム基礎における $\bar{a}_{\max }$ は小さい. 卓越周波数が $0.59 \mathrm{~Hz}$ である Case 1 は 任意の $y / H$ に対して 8 波中最大となり, 天端での $\bar{a}_{\text {max }}$ は $\ddot{u_{g}}$ に対してほぼ 3.5 倍となっている. Case 4 の地震 動の卓越周波数は堤体の固有周波数に最も近いが, Case 4 の $\bar{a}_{\max }$ は Case 1 と比べて天端で約 $300 \mathrm{gal}$ 程度 小さく, 卓越周波数だけでは天端における $\bar{a}_{\max }$ の大小 の傾向はつかめないことがわかる.なお, Case 1 のフ 一リエスペクトルは， 0.3 秒以上の長周期成分が卓越し た正弦波に近い波である.また，堤体の固有周期である 0.6 秒以上の長周期成分が多い Case 1，2，3，5は，他 の地震動に比べて $\bar{a}_{\max }$ が全体的に大きい.

Fig.11 は，入力 8 波形に対する $\bar{a}_{\max }$ の平均值を $\ddot{u}_{\max }$

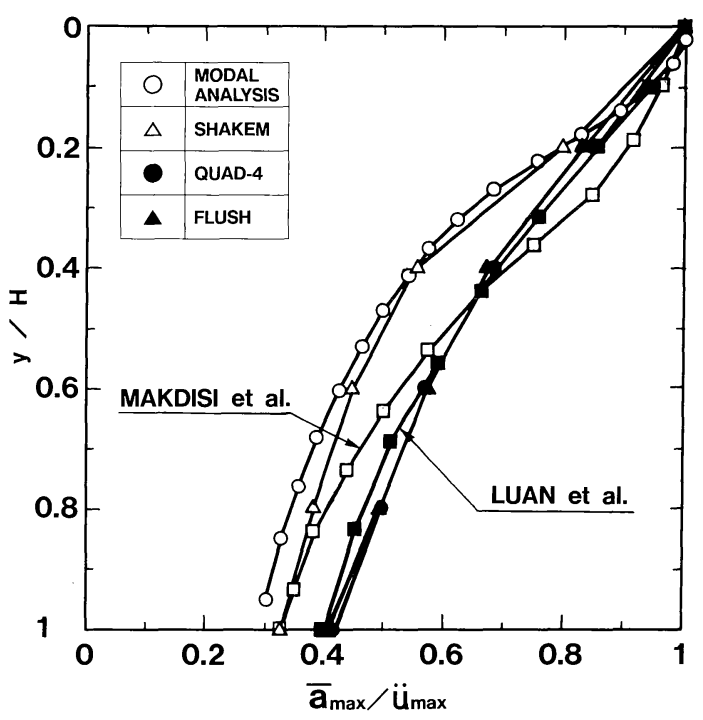

Fig.11 Comparison of normalized maximum acceleration curve with depth of sliding mass

で除して求めた加速度曲線である.なお，Fig.11 は， Makdisi et al. ${ }^{4)}$ とLuan et al. ${ }^{10)}$ の結果も記入してあ る. 本論文の 2 次元動的解析の加速度曲線は, Luan et al. の分布とほぼ一致しており, Makdisi et al.の結果と は若干異なっている. Luan et al. は築堤材料のせん断 弾性係数を拘束圧に依存させて解析しているのに対し, Makdisi et al. ではせん断弾性係数を一定と仮定してお り,このせん断弾性係数の設定方法が $\bar{a}_{\max }$ の分布に影 響を与えているものと考えられる. 1 次元動的解析によ る加速度曲線は 2 次元動的解析に比べて左側にずれ, 円 弧高さ $y / H$ が 0.3 以上でほぼ平行であるが，これは 1 次元動的解析における $\ddot{u}_{\text {max }}$ が大きいために相対的にず れたものである.

Makdisi et al. や Luan et al. は, 加速度曲線を Fig.11 の曲線で表してすべり量の算定に用いているが, この分布は単に平均值にすぎず, 地震動の周波数特性と 堤体の固有周波数の関係は省略されている， $\bar{a}_{\max }$ は

Fig.10に示すようにこれらの関係に大きく左右され, Case 2, 3 の地震動に対しては中位標高の $\bar{a}_{\max }$ に対して $\ddot{u}_{\text {max }}$ が相対的に小さいから Fig.11の分布を適用すると 中低標高部での $\bar{a}_{\max }$ を過小評価してしまうことになる. したがって, 加速度曲線を用いて地震力を決めるとき, これらのことを考慮せずに単純に $\ddot{u}_{\max }$ を設定して各標 高の $\bar{a}_{\max }$ を推定すると大きな誤差を生じる恐れがある. 設定された加速度曲線で各標高における $\bar{a}_{\max }$ の分布を 推定する手法は簡便であるが，以上のような問題点があ り, むしろ $\ddot{u}_{g}$ と Fig.10を組み合わせて入力地震動の周 波数特性に応じて $\bar{a}_{\max }$ の分布を求めた方が実務上誤り が少ないと考えられる. 


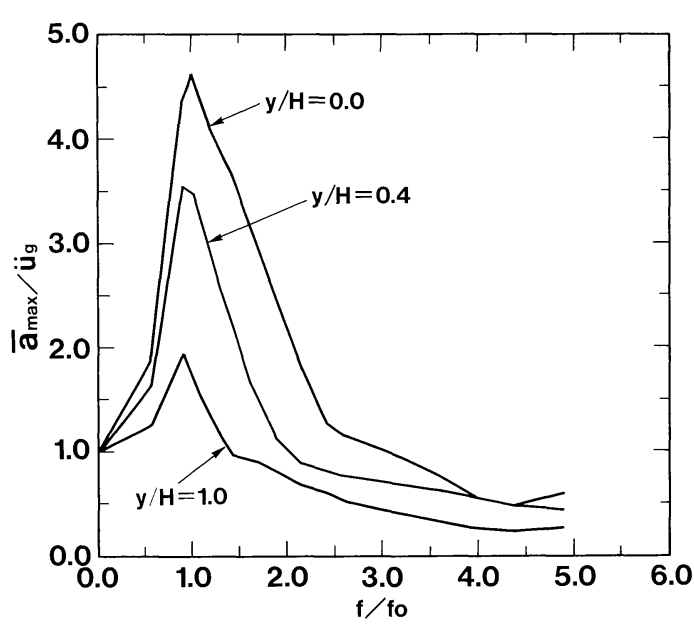

Fig.12 Frequency response functions of $\bar{a}_{\max }$ from QUAD-4

\section{5. 最大平均加速度簡易推定手法}

円弧すべり土塊の $\bar{a}_{\max }$ は入力地震動の周波数特性に 依存しており，周波数特性が異なれば応答は異なってく る. 以下では，実地震動において $\bar{a}_{\max }$ に与える影響の 大きい周波数成分の評価方法について検討した.

一般に構造物の任意の点の変位や応力などの物理量 $R$ が，単位の振幅で周波数が $f \mathrm{~Hz}$ の正弦波が入力した とき $f$ の関数 $R(f)$ で表されるとすれば， $R(f)$ は周波 数応答関数である。そこである $y / H$ のすべり土塊の $\bar{a}_{\text {max }}$ を多くの周波数 $f$ に対して計算により求めた.

Fig.12 は Fig.1のダムの周波数応答関数を QUAD-4 を 用い $y / H=0.0,0.4,1.0$ の 3 標高で求めたものである. 各すべり土塊の $\bar{a}_{\max }$ は $f / f_{0}=1.0$ 付近でピーク值をとっ ているが, $y / H$ により $\bar{a}_{\max } / \ddot{u}_{g}$ の值が異なっている.

前述のように Makdisi et al. は地盤の加速度応答ス ペクトルが荷重条件として与えられたとき，これを用い て $\ddot{u}_{\max }$ を推定し，さらにFig.11 の加速度曲線と組み合 わせて $\overline{a_{\max }}$ の設計值を求める手法を提案している. 一 方, Fig.12に示す $\bar{a}_{\max }$ の周波数応答関数が存在するこ ととその特性に着目すれば，荷重条件として与えられた 加速度応答スペクトルから直ちに精度よく $\bar{a}_{\max }$ を求め ることが可能なはずである。すなわち入力される地震動 の加速度応答スペクトルが与えられたとき，フィルダム の地震時の応答には固有周波数が 5 ～ 6 次までの低次の 周波数が支配的であり，種々の試算の結果も踏まえ式 ( 7 )を主要な周波数範囲と考えた.

$$
0.8 \leqq f / f_{0} \leqq 2.0 \cdots
$$

式( 7 )で示される周波数領域における加速度応答スペク トルの平均値 $S_{a m}$ を算出し, これと動的解析から算出 される $\bar{a}_{\max }$ の間に相関があれば， $S_{a m}$ から簡易に $\bar{a}_{\max }$ を算定することが可能となる. 入力地震動として Table

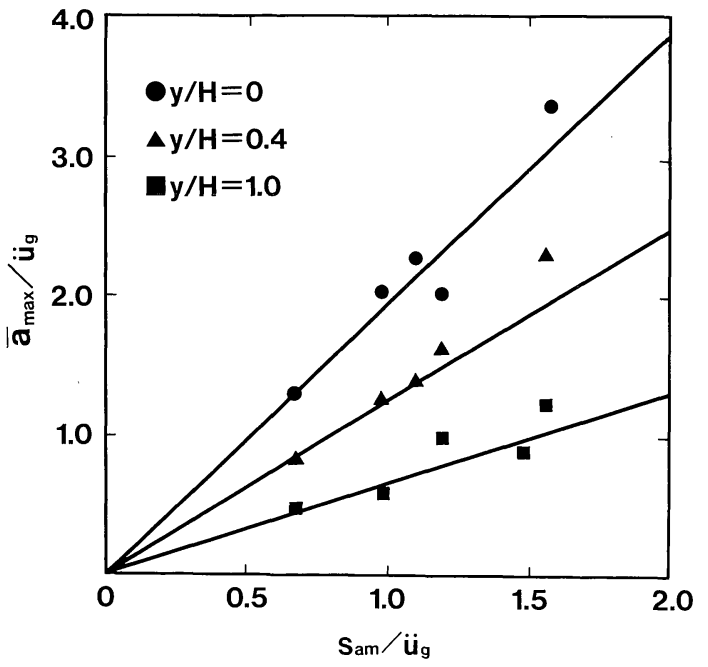

Fig.13 Relationship between $\bar{a}_{\max } / \ddot{u}_{g}$ and $S_{a m} / \ddot{u}_{g}$ from QUAD-

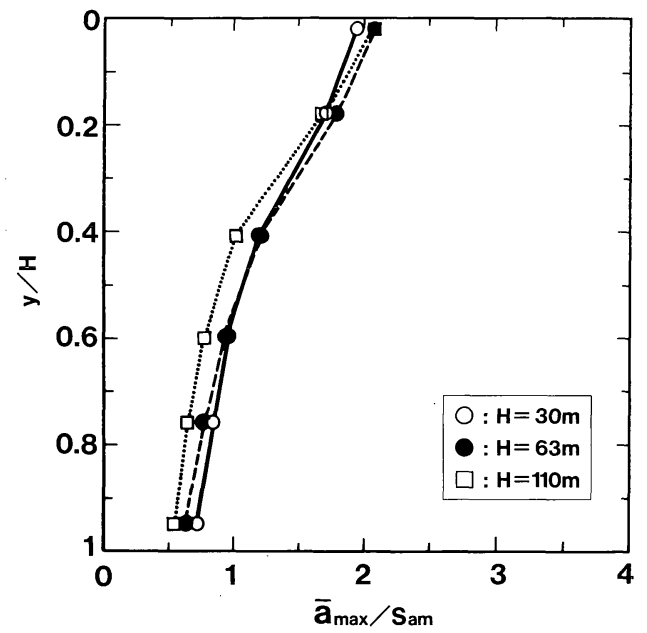

Fig.14 Relationship between $\bar{a}_{\text {max }} / S_{a m}$ and $y / H$ for three different dam-heights from MODAL ANALYSIS

1 の 8 個の地震動を用い, Fig.4 から $S_{a m}$ を算出し QUAD-4 から求めた $\bar{a}_{\max }$ との関係を図示したものが Fig.13である.

また，前述のようにダムの堤高（固有周期）がすべり 土塊の $\bar{a}_{\max }$ に及ぼす影響ついては，Fig.14に示す。た だし，ここでは QUAD-4ではなく計算が簡便な 1 次元 のモード重畳法により検討を行った.これによれば，堤 高が異なっても $\bar{a}_{\max } / S_{a m}$ は $y / H$ に対して差がないこと を示している.

以上は減衰定数 $h$ を $20 \%$ とした結果である. $h=10 \%$ とした場合について新たに応答スペクトルを求め直し, $\bar{a}_{\max } / S_{a m}$ と $y / H$ の関係を求め $h=20 \%$ の場合と比較す ると Fig.15 となる，なお，図中の $R_{0.1}, R_{0.2}$ は，それ 


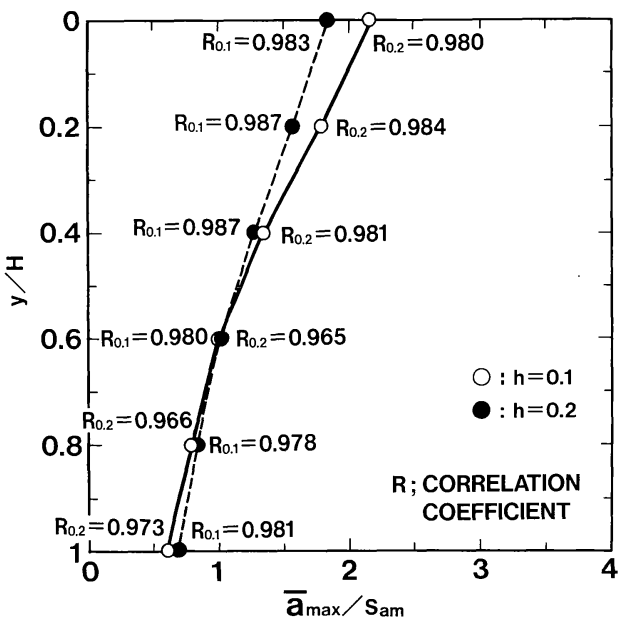

Fig.15 Relationship between $\bar{a}_{\max } / S_{a m}$ and $y / H$ for $h=10 \%$ and 20\% from QUAD-4

ぞれ $10 \%$ と $20 \%$ の減衰定数の場合 Table 1 の 8 波の入 力地震動に対する $\bar{a}_{\max } / \ddot{u}_{g}$ のばらつきの図中の回帰曲線 との相関係数である. QUAD-4を用いた 2 次元動的解 析の結果では, $h=10 \%$ と $20 \%$ の差は小さく, 近似式 として次式が成り立つ.

$$
\bar{a}_{\text {max }}=\{2.0-1.35(y / H)\} \times S_{a m} \cdots
$$

以上の結果から，すべり土塊の $\bar{a}_{\max }$ は以下の手順を 踏むことで簡易に推定できる.

(1) 地震動の加速度応答スペクトルを算出する.この とき減衰定数は, 対象とするダムの減衰定数とする.

(2) ダム堤体の固有周波数を算定する.

(3) 加速度応答スペクトルの平均值 $S_{a m}$ を式( 7 ) の 周波数領域を対象として算出する.

(4) $S_{a m}$ を式（８）に代入して，あるいはFig.15から 各標高におけるすべり土塊の $\bar{a}_{\max }$ が算出される.

\section{6. $\bar{a}_{\max }$ を用いた残留ひずみの推定}

堤体内のあるすべり土塊の限界加速度を $a_{y}$ し, 入力 地震動によるそのすべり土塊の最大平均加速度が $\bar{a}_{\max }$ であるとき， $a_{y} / \bar{a}_{\max } \geqq 1.0$ であれば永久変形量 $U_{p}$ は発 生しないが， $a_{y} / \bar{a}_{\max }<1.0$ のときには， $U_{p}$ が生じ， $U_{p}$ は $a_{y} / \bar{a}_{\max }$ の值と強い相関があり， $U_{p}$ を $a_{y} / \bar{a}_{\max }$ から推 定するチャートがMakdisi et al. ${ }^{4)}$, Luan et al. ${ }^{10)}$ によ り提案されている.この考えは基本的には Newmark ${ }^{1)}$ の方法を発展させたものである.本論ではこれとは別に， $\bar{a}_{\text {max }}$ を用いて室内試験により残留ひずみを推定する方 法を示す. 石原 ${ }^{27)}$ は堤体内のすべり土塊について地震 前の常時荷重による安全率と地震時の安全率をスライス 法によって求めこれから静的および動的せん断応力を推 定し,この応力条件での室内試験から残留ひずみを求め る方法を提案している. 本論文もこの考え方によるが，

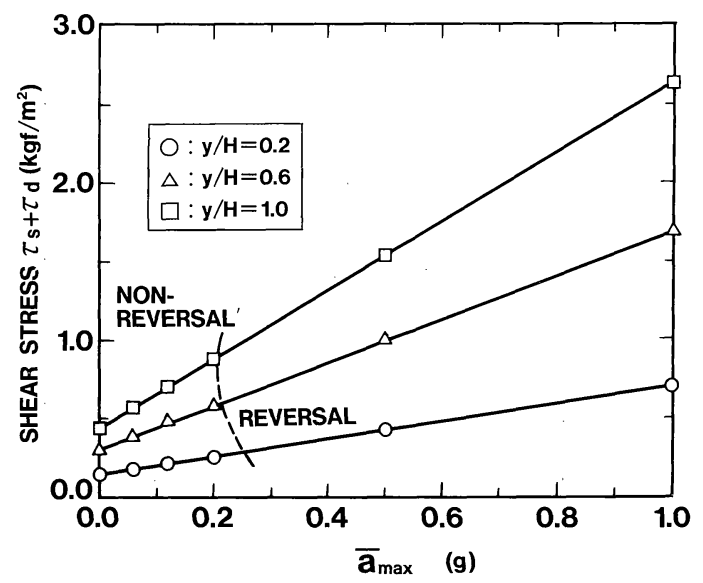

Fig.16 Shear stresses estimated by using $\overline{a_{\max }}$

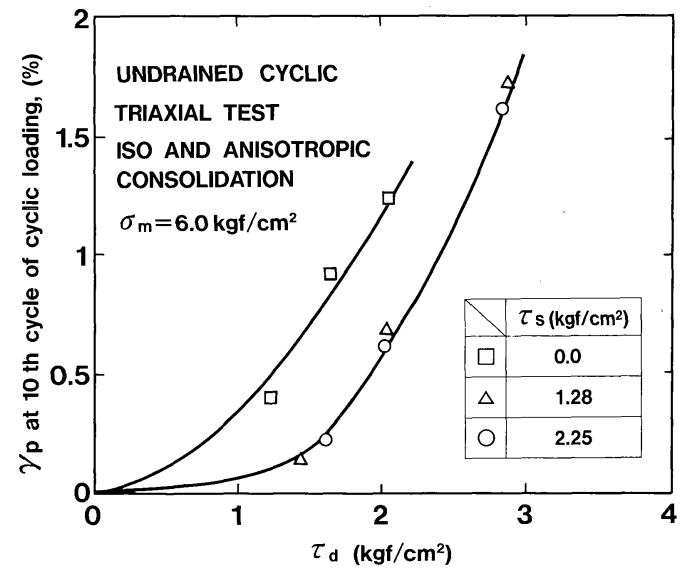

Fig.17 Permanent strain development in undrained cyclic triaxial test

$\bar{a}_{\max }$ を用いて直接動的せん断応力を推定することとす る. 地震前に常時荷重によるすべり土塊のモーメントを $M_{s}$ とすると, 常時荷重による平均的なせん断応力 $\tau_{s}$ は $r$ を円弧半径, $l$ を円弧長さとして

$$
\tau_{s}=\frac{M_{s}}{r \cdot l}
$$

一方，地震荷重によるモーメント $M_{d}$ は $\bar{a}_{\max }$ から求 めることができ, 地震による平均的なせん断応力 $\tau_{d}$ は

$$
\tau_{d}=\frac{M_{d}}{r \cdot l}
$$

堤体材料の供試体を平均的な拘束圧 $\sigma_{m}$ で圧密し, 排水 条件で $\tau_{s}$ を載荷し $\pm \tau_{d}$ の繰返しせん断応力を非排水条 件で載荷し, 残留ひずみ $\gamma_{p}$ を求める. なお, 載荷応力 の波形は $\bar{a}$ の時刻歴から定めることが望ましいが，一 定振幅のときには $\bar{a}_{\max }$ の代りに $\bar{a}_{e q}$ を用いる. Fig.16 はFig.2(b)のモデルダム上流面のすべり土塊の $\bar{a}_{\max }$ と すべり面のせん断応力 $\tau\left(\tau_{s}+\tau_{d}\right)$ の関係についての計算 結果である. Fig.16の $\overline{\bar{a}}_{\max }=0$ のとき $\tau$ は式 $(9)$ 
より求められた $\tau_{s}$ であり， $\tau_{d} \leqq \tau_{s}$ となる $\tau_{d}$ の範囲が図 中に破線で示されている. この図から $\bar{a}_{\text {max }}$ が $0.2 \mathrm{~g}$ 程 度以下では $\tau_{d}$ は $\tau_{s}$ より小さく, 応力反転は生じてない ことがわかる. 以上のように, Fig.16を利用して $\tau_{d}$, $\tau_{s}$ を設定すれば, 室内繰返し載荷試験における $\tau_{d}$ およ び $\tau_{s}$ を簡易でかつ適切に定めることができる.

Fig.17 は, ロック材料の繰返し載荷試験28) より求め た繰返し載荷回数 $N=10$ 回の $\gamma_{p}$ 之 $45^{\circ}$ 面上の $\tau_{d}$ の関係 を示す. Fig.16 から, あるいは式( 9 ), (10)から対象 とするすべり土塊に対する $\tau_{s}$ 之 $\tau_{d}$ を求め, この $\tau_{s}$ 之 $\tau_{d}$ を Fig.17に適用すれば, $N=10$ 回の繰返し載荷した ときの永久ひずみ $\gamma_{p}$ を推定することができる，ただし， Fig.17 は平均主応力 $\sigma_{m}=6.0 \mathrm{kgf} / \mathrm{cm}^{2}$ の場合であり, ロック材のせん断強度には拘束圧依存性があるから実験 では平均主応力を何段階か変えて Fig.17 の曲線を求め ておく必要がある。

\section{7. 結 論}

種々の周波数特性を持つ地震動が, フィルダム堤体の 地震力に及ぼす影響を 4 種類の動的解析手法を用いて評 価し， $\bar{a}_{\max }$ の簡易推定手法について検討した. 得られ た結論を以下に要約して示す.

（1）入力地震動は，水平成分のみとし，堤体応答加 速度も水平成分のみを用いて $\bar{a}_{\max }$ を求めても, 入力お よび応答において水平, 鉛直 2 成分を考慮したときに比 べ, 高々 $10 \%$ 程度の誤差であり, 水平成分のみから $\bar{a}_{\max }$ を求めることができる.

（2） $\bar{a}_{\text {max }}$ は，対象とするすべり土塊について等価 なモーメントおよび水平合力から求める 2 方法がある が，両者の差は最大で $5 \%$ 程度である. すなわち計算が より簡単な水平合力から $\bar{a}_{\max }$ が求められる.

（3）種々の周波数特性を持つ 8 波の地震動に対して 4 種類の解析方法で $\bar{a}_{\max }$ の分布を求めると, 1 次元解 析である質点系モード重畳法およびSHAKEMは，8入 力波に対する平均で，天端における応答加速度が $15 \%$ 程度 2 次元解析よりも大きい. $y / H>0.3$ の標高では解 析方法による $\bar{a}_{\max }$ のばらつきは $10 \%$ 以下であり, 1 次 元解析による天端付近の応答がやや大きめの点を除けば 全体に解析方法によるばらつきは小さい.

（4） $\bar{a}_{\max }$ は $\ddot{u}_{g}$ が同一であっても, 周波数特性によっ て 8 波の平均を基準として $\pm 50 \%$ 変動する.したがっ て, 実務において, $\ddot{u}_{\max }$ で無次元化された Makdisi et al. による加速度曲線の平均值を用いるときには, 当該 サイトで想定される地震動の周波数特性との関連を検討 すべきである.

（５）入力地震動の加速度応答スペクトルが与えられ たとき, $y / H$ の值に応じて式 $(7)$ の周波数範囲につい てのスペクトルの平均值 $S_{a m}$ を求めれば, 式 $(8)$ ある
いはFig.15 から $\bar{a}_{\max }$ を簡易に推定することができる.

(6) $\bar{a}_{\text {max }}$ から式(9)および式(10)を用いて静的お よび地震力によるせん断応力を推定し，これを用いて堤 体材料の室内繰返し試験を実施すれば，地震力により堤 体に生じる残留ひずみの推定が可能となる.

\section{参考文献}

1) N.M. Newmark : Effects of Earthquakes on Dams and Embankments, Geotechnique, Vol.15, No.2, pp. 139 $160,1965$.

2) H.B. Seed : A Method for Earthquake-Resistant Design of Earth Dams, Jour. of SMFD, Vol.92, NO. SM 1, pp. 13 $\sim 41,1966$.

3) H.Watanabe, S.Sato and K.Murakami : Evaluation of Earthquake-Induced Sliding in Rockfill Dams, Soils and Foundations, Vol.24, No.3, 1984.

4) F.I. Makdisi and H.B. Seed : Simplified Procedure for Estimating Dam and Embankment Earthquake-Induced Deformations, GT. 7, ASCE, Vol.104, PP. 849 867, 1978.

5) H.B. Seed and G.R. Martin: The Seismic Coefficient in Earth Dam Design, Jour. of SMFD, ASCE, Vol.92, NO. SM 3, pp.25 58, 1966.

6) N.N. Ambraseys and S.K. Sarma : The Response of Earth Dams to Strong Earthquakes, Geotechnique, Vol.17, pp. 181 213, 1967.

7) N. Mononobe, A. Tanaka and M. Matsumura: Seismic Stability of the Earth Dams, 2 nd ICOLD, pp. 435 444, Vol.IV, 1936.

8) A.K. Chopra : Earthquake Response of Earth Dams, Jour. of SMFD, ASCE, Vol.93, NO. SM 2, pp. 65 81, 1967.

9) F.I. Makdisi and H.B. Seed : Simplified Procedure for Evaluating Embankment Response, Vol.105, GT 12, ASCE, pp.1427 1434, 1979.

10) M.T. Luan, C.P. Jin, G. Lin and H. Takemiya : Parametric Studies on Dynamic Stability and Permanent Deformations of Cohesive Embankment, Proceedings of the Eighth Japan Earthquake Engineering Symposium, Vol.1, pp. 975 〜980, 1990.

11）松本徳久 - 安田成夫 ·大久保雅彦・木下靖: 粗粒材料の せん断強度之動的変形特性, 土木学会論文集, 第 424 号 /III-14, pp. 95 104, 1990.

12）松本徳久・豊田光雄・志賀三智：ロックフィルダムの模 型振動実験, 土木技術資料, Vol. 25, No. 6, pp. 45 50, 1983.

13) T.Ohmachi and N.Nakamoto : In-Situ Measurement of Radiation Damping of Existing Rockfill Dams, Proceedings of 9 th World Conference on Earthquake Engineering, [VI], pp.337 -342, 1989.

14) Ashok K. Chugh : Dynamic Response Analysis of Embankment Dams, International Journal for Numerical and Analytical Methods in Geomechanics, Vol.9, pp. 101 -124, 1985.

15) I.M. Idriss, J. Lysmer, R. Wang and H.B. Seed : QUAD- 
4. A Computer Program for Evaluating the Seismic Stability of Soil Structures by Variable Damping Finite Element Procedures, EERC-Report No.73-16, University of California, 1973.

16) J. Lysmer, T. Udaka, C-F. Tsai and H.B. Seed : FLUSHA Computer Program for Approximate 3-D Analysis of Soil Structure Interaction Problems, EERC-Report No.7530, University of California, 1975.

17）岡本舜三：建設技術者のための振動学（第 2 版), オーム 社, pp. 57-66, 1976.

18) P.B. Schnabel, J.Lysmer and H.B. Seed : SHAKE,A Computer Program for Earthquake Response Analysis Horizontally Layered Sites, EERC-Report No.72-12, University of California, 1972.

19）松本徳久・近藤悟・片平博・志賀三智：ダムサイト岩盤 における地震動, 土木研究所資料, No. 1789, 1982.

20）田村重四郎・岡本舜三：フィルダムの安定性に対する地 震の上下動の影響について, 大ダム, No. 127, pp. 78〜85, 1989.

21）松本徳久・安田成夫・山邊建二：フィルダムに作用する
地震力の評価, 土木研究所資料, 第 2997 号, 1991.

22）岡本舜三: 耐震工学, オーム社, p. 385, 1971.

23) T. Sawada : Behavior of Fill-type Dam during Earthquakes Case Study of Namioka Dam. Proc. Japan Acad.62, Ser. B, pp. 201 204, 1986.

24）安中正実：フィルダムの地震観測および三方向地震入力 三次元モード重畳解析, 大ダム, No. 134, pp. 22 34, 1990.

25）長谷川高士・内田一徳・菊沢正裕・村上章：深山ダムの 地震応答データの分析と動的挙動の予測, 農業土木学会 論文集，第 108 号，pp. 55 63，1983 年 12 月.

26）沢田敏夫・長谷川高士・菊沢正裕：複合減衰モデルの実 ダム動的解析への適用農業土木学会論文集, 第 28 号, pp. 58〜64，1979 年 8 月.

27）石原研而：土構造物の耐震設計法の現状と問題点, 土之 基礎, No. 28-8, pp. 3〜8, 1980.

28）松本徳久. 安田成夫 ·大久保雅彦・芳岡良一：ロック材 料の単調載荷および繰返し載荷試験, 土木研究所資料, 第 2996 号, 1991.

(1991. 12.19 受付)

\section{EVALUATION OF SEISMIC FORCE ACTING ON EMBANKMENT DAMS AND ITS SIMPLIFIED PREDICTION PROCEDURE}

Norihisa MATSUMOTO, Nario YASUDA and Kenji YAMABE

Seismic force acting on embankment dams is studied by using one and two dimensional dynamic analyses. In this report, using acceleration records of actual earthquakes, the distribution of seismic accelerations in the typical dam body section is computed. On the basis of reponse computations to different input motions having various frequency characteristics, a relationship for the induced maximum acceleration with frequency charateristics of the ground motions is established.

A simplified procedure is also presented for estimating the maximum average acceleration of potential sliding masses of various depths from acceleration response spectrum of ground earthquake motions. 